\title{
Strategi Implementasi Pendidikan Karakter di Masa Pandemi Covid-19; Studi Kasus di MAN 2 Banyuwangi
}

\author{
Rasmuin $^{1}$, Saidatul IImi ${ }^{2}$ \\ ${ }^{1,2}$ Fakultas Ilmu Tarbiyah dan Keguruan UIN Maulana Malik Ibrahim Malang \\ ${ }^{1}$ muin@uin-malang.ac.id, ${ }^{2}$ saidatulilmi123@gmail.com
}

\begin{abstract}
All this time, character education can be done well through offline learning in schools. Teachers can control student activities in school directly during learning. The problem arose when Covid-19 began to plague which required offline learning to be eliminated and replaced with online learning. This study aims to reveal how the strategy of MAN 2 Banyuwangi as one of the favorite schools in implementing character education in the Covid-19 pandemic era. Data collection was carried out through observation where the researcher went directly to the field to observe the learning process. Data collection was also carried out through interviews with related parties, as well as documentation obtained from learning activities during the pandemic. The data were then analyzed through three stages, namely data reduction, data presentation, and drawing conclusions. From this research, it can be concluded that in carrying out character education during the Covid-19 pandemic there are at least three main things done by the school. First, forming a distance learning atmosphere is exactly the same as studying in school. Second, be consistent in implementing the school culture that is usually done in schools and still adapting to existing conditions. Third, establish solid cooperation between schools and parents.
\end{abstract}

Keywords: Challenges and Strategies, Character Education, The Covid-19 Pandemic.

\begin{abstract}
Abstrak
Selama ini pendidikan karakter bisa dilakukan dengan baik melalui pembelajaran tatap muka secara langsung di sekolah. Guru bisa secara langsung mengontrol kegiatan siswa di lapangan selama pembelajaran berlangsung. Masalah muncul ketika Covid-19 mulai mewabah yang mengharuskan pembelajaran tatap muka ditiadakan dan diganti dengan pembelajaran online. Pendidikan karakter yang selama ini dilakukan secara langsung otomatis ikut terganggu. Penelitian ini berusaha mengungkap bagaimana strategi MAN 2 Banyuwangi sebagai salah satu sekolah favorit dalam menerapkan pendidikan karakter di era pandemi Covid-19. Pengumpulan data dilakukan melalui observasi di mana peneliti terjun langsung ke lapangan untuk mengamati proses pembelajaran jarak jauh. Pengumpulan data juga dilakukan melalui wawancara dengan pihak terkait, serta dokumentasi yang diperoleh dari kegiatan pembelajaran selama pandemi.
\end{abstract}


Data yang diperoleh kemudian dianalisis melalui tiga tahapan yaitu reduksi data, penyajian data, dan penarikan kesimpulan. Dari penelitian ini bisa diambil kesimpulan bahwa dalam melaksanakan pendidikan karakter selama pandemi covid-19 ini setidaknya ada tiga hal utama yang dilakukan oleh pihak sekolah. Pertama, membentuk suasana belajar jarak jauh sama persis dengan belajar di sekolah. Kedua, konsisten menerapkan budaya sekolah yang biasa dikerjakan di sekolah dan tetap menyesuaikan dengan kondisi yang ada. Ketiga, menjalin kerja sama yang solid antara sekolah dan orang tua.

Kata Kunci: Tantangan dan Strategi, Pendidikan Karakter, Pandemi Covid-19

\section{Pendahuluan}

Saat ini pemberitaan terkait pandemi Covid-19 masih menjadi topik menarik dan diperhatikan oleh banyak masyarakat dunia. Seperti yang telah diketahui, bahwa virus yang hampir menjangkit seluruh negara di dunia ini memiliki pola persebaran yang masif dan cepat, sehingga kerap memunculkan korban yang kian meningkat setiap harinya. Gejala yang muncul pada virus ini umumnya seperti demam, batuk, bersin, hingga peradangan dan sesak nafas. Melihat semakin tingginya tingkat penyebaran Covid-19, diharapkan tiap-tiap komponen masyarakat sadar dan tanggap akan upaya yang harus segera dilakukan.Untuk mengantisipasi serta mencegah secara komprehensif terkait dengan penyebaran virus ini semua kalangan harus satu visi dan misi saling membantu dalam penanganannya.

Selain itu, dampak yang dialami oleh negara-negara yang terjangkit virus ini, juga cukup terasa di berbagai sektor kehidupan. Aspek ekonomi, sosial, agama, politik, dan tak terkecuali juga dalam sektor pendidikan semua merasakan efek dahsyat massifnya penyebaran virus ini. Seiring berjalannya waktu, pemerintah dituntut untuk terus membuat kebijakan-kebijakan yang mampu melindungi kesehatan dan kebutuhan masyarakat di berbagai sektor yang terdampak. Aturan untuk membiasakan diri untuk mencuci tangan, memakai masker, dan menjaga jarak menjadi kebijakan paling awal diambil untuk meminimalkan penularan wabah. Tentu saja kebijakan ini juga memunculkan problematika baru bagi masyakarat terutama mengenai kebijakan menjaga jarak. Sektor-sektor terdampak ini juga selanjutnya diharuskan untuk menciptakan inovasi-inovasi kreatif untuk tetap survive dalam menghadapi pandemi.

Dunia pendidikan menjadi salah satu sektor yang sangat merasakan dampak dalam pandemi ini. Kebijakan yang diambil oleh pemerintah tentang menjaga jarak yang akhirnya melahirkan kebijakan baru mengenai pelarangan pembelajaran tatap muka menjadi ujian berat dalam sistem pendidikan di negeri ini. Proses pembelajaran 
yang biasanya dilakukan secara tatap muka tidak bisa lagi dilakukan selama wabah. Pembelajaran yang mencakup aspek kognitif, afektif dan psikomotor menjadi tidak maksimal ketika dilakukan melalui pembelajaran jarak jauh. Pada saat inilah lembaga pendidikan diuji untuk tetap mampu melaksanakan berbagai aspek pembelajaran secara optimal.

Pendidikan karakter yang selama ini menjadi program prioritas pemerintah otomatis juga merasakan dampak dari pemberlakuan pembelajaran jarak jauh. Untuk bisa terlaksana secara efektif setidaknya pendidikan karakter ini membutuhkan tiga aspek antara lain desain pendidikan berbasis kelas, desian pendidikan berbasis kultur sekolah, dan desain pendidikan berbasis komunitas. ${ }^{1}$ Hal inilah yang menjadi tantangan tersendiri pada sebuah lembaga pendidikan untuk tetap bisa menanamkan karakter unggul kepada para peserta didiknya meskipun pembelajaran dilaksanakan tanpa tatap muka secara langsung melalui berbagai platform media online. Lembaga pendidikan harus mampu membuat inovasi sedemikian rupa dalam menyesuaikan pembelajaran selama pandemi dengan tidak mengabaikan ketercapaian tujuan pendidikan.

Ketercapaian kualitas sistem pendidikan pada suatu lembaga pendidikan pastinya tidak akan lepas dari adanya sistem atau kebijakan yang diselenggarakan secara maksimal di dalamnya. Pengembangan serta pelaksanaan yang sistematis dan rapi dalam suatu lembaga pendidikan, seperti perencanaan, pengelolaan, implementasi kebijakan lembaga, dan sebagainya, pasti juga menjadi nilai positif dalam upaya menunjang keberhasilan suatu lembaga pendidikan. Mengingat pendidikan merupakan aspek penting dalam suatu negara, yang mampu membantu kelangsungan pertumbuhan dan pembangunan suatu negara dalam upaya mencapai peradabannya.

Secara hakikat, sebenarnya pendidikan bukanlah sesuatu yang muncul pertama kali melalui proses yang harus dikelola secara sistematis dan terstruktur. Namun pendidikan dapat dikatakan sebagai bagian dari proses kehidupan yang berlangsung sejak manusia tercipta. Proses pendidikan yang terjadi pada manusia, dapat kita katakan sebagai proses yang terjadi begitu saja, menyesuaikan dengan kebutuhan manusia pada saat itu, yakni sesuai pada tingkat usianya dan bukan merupakan hal yang direncanakan. Pendidikan dipandang sebagai sebuah pusat kehidupan yang dinilai memiliki urgensi

\footnotetext{
${ }^{1}$ Adi Suprayitno and Wahid Wahyudi, Pendidikan Karakter Di Era Milenial (Yogyakarta: Deepublish, 2020).
} 
besar dalam upaya meningkatkan stabilitas diri seseorang. ${ }^{2}$ Oleh karenanya, ketika proses ini mulai disadari, bahwa pendidikan adalah penting dalam menunjang kemajuan, maka diolahlah pendidikan ini sedemikian rupa serta dirumuskan beberapa aspek di dalamnya agar lebih tertata dan berdimensi positif serta menjadi sarana dalam mewujudkan cita-cita masyarakat dan bangsa. Arah yang dituju dalam proses pendidikan sendiri adalah bagaimana proses yang terlaksana dapat menghasilkan progres yang baik, hingga mencapai pada standar output ideal. Ideal yang dimaksud di sini dimaknai sebagai manusia yang memiliki kecerdasan atau intelektual yang baik, keterampilan dalam berbagai hal serta dibarengi dengan pembentukan sikap positif yang berorientasi pada terbentuknya akhlak atau moral yang baik dalam diri manusia, agar sikap dan tindakan dapat berjalan secara seimbang. Di sinilah peran guru merupakan salah satu pokok penting penunjang keberlangsungan pendidikan untuk memobilisasi atau memegang kendali proses ini serta menjadi pembimbing utama dalam mewujudkan terbentuknya manusia ideal atau output yang berkualitas. ${ }^{3}$

Dalam dunia pendidikan sekarang, dampak Covid 19 menjadikan seluruh pihak baik dari pemegang kebijakan yang paling tinggi di dunia pendidikan hingga pada pendidik, masing-masing dituntut untuk mempunyai dan mengembangkan inovasinya dalam pelaksanaan pendidikan yang diharuskan untuk tidak diselenggarakan secara tatap muka. Hal tersebut menjadikan kegiatan belajar jarak jauh menjadi salah satu alternatif atau jalan tengah dari problem belajar tersebut. Namun perlu diketahui pula bahwa dengan kondisi pembelajaran jarak jauh pastinya juga harus didukung oleh media pendukung yang dapat menunjang keberlangsungan pendidikan siswa. ${ }^{4} \mathrm{Hal}$ ini pastinya menjadi sebuah tantangan tersendiri bagi berlangsungnya proses pendidikan.

MAN 2 Banyuwangi merupakan salah satu madrasah favorit yang berada di Kabupaten Banyuwangi. Madrasah yang dilengkapi dengan berbagai fasilitas yang lengkap ini memiliki visi "Terwujudnya Insan Berprestasi dan Berakhlak Mulia Berlandaskan Iman dan Takwa." Dengan visi ini terlihat bahwa madrasah ini sangat peduli terhadap pendidikan karakter para peserta didiknya. Madrasah ini berusaha mencetak lulusannya sebagai insan cendekia serta berkarakter unggul. Dalam rangka mewujudkan visi misinya, madrasah ini dilengkapi dengan Ma’had al Qasimi sebagai

\footnotetext{
2 Tohir Kholis and M. Syukri Azwar Lubis, Model Pendidikan Pesantren Salaf (Surabaya: Scopindo Media Pustaka, 2020).

${ }^{3}$ Doni Koesoema, Pendidikan Karakter Di Zaman Keblinger (Jakarta: Grasindo, 2016).

${ }^{4}$ F. Ridwan Sanjaya, ed., 21 Refleksi Pembelajaran Daring Di Masa Darurat (Semarang: UNIKA Soegijapranata, 2020).
} 
kawah candradimuka bagi para peserta untuk secara intens menanamkan pendidikan karakter.

Masalah muncul ketika kebijakan pemerintah yang melarang adanya pembelajaran tatap muka. Pendidikan karakter yang sudah didesain dengan baik oleh pihak madrasah menjadi terganggu. Desain pembelajaran berbasis kelas, berbasis kultur madrasah, dan berbasis komunitas yang menjadi syarat efektifitas proses pendidikan karakter menjadi terhambat akibat adanya kebijakan ini. Sehingga pihak sekolah bersama para stakeholder diharuskan untuk mencari strategi untuk mengatasi problematika yang dihadapi. Berkatian dengan itu, hasil penelitian yang dilakukan oleh I Putu Yoga Purandina dan I Made Astra Winaya mengungkapkan bahwa kerjasama yang baik antara sekolah dengan orang tua dalam proses pembelajaran jarak jauh selama pandemi ini mampu untuk menjaga proses pendidikan karakter terlaksana secara optimal..$^{5}$ Demikian pula hasil penelitian Galih, dkk yang menemukan bahwa proses pembiasaan pada pendidikan karakter dapat tercapai dengan adanya sinergitas antara implementasi kurikulum, kebijaksanaan guru serta peran orang tua sebagai asesor pendidikan karakter anaknya masing-masing. ${ }^{6}$ Selanjutnya, I Wayan Santika juga menyatakan bahwa strategi pendidikan karakter multiplle intelligences berbasis portofolio bisa menjadi solusi dalam menyukseskan pendidikan karakter dalam proses pembelajaran jarak jauh. ${ }^{7}$ Dari uraian di atas, tulisan ini memfokuskan pada bagaimana strategi MAN 2 Banyuwangi dalam melaksanakan internalisasi nilai-nilai karakter secara optimal di masa pandemi Covid-19 ini melalui kegiatan belajar mengajar yang dilaksanakan secara online. Peneliti juga berusaha untuk menggali problematika dan solusi yang diambil oleh MAN 2 Banyuwangi dalam proses pembelajaran jarak jauh ini.

\section{Metode}

Penelitian ini merupakan penelitian deskriptif kualitatif. Pengumpulan data dilakukan melalui observasi di mana peneliti terjun langsung ke lapangan untuk mengamati proses pembelajaran jarak jauh. Peneliti bergabung secara langsung ke dalam kelas-kelas virtual yang dilaksanakan oleh guru untuk mengamati proses

\footnotetext{
${ }^{5}$ I Putu Yoga Purandina and I Made Astra Wanaya, "Pendidikan Karakter Di Lingkungan Keluarga Selama Pembelajaran Jarak Jauh Pada Masa Pandemi COVID-19," Jurnal Ilmu Pendidikan 3, no. 2 (2020): 273.

${ }^{6}$ Galih Mustikaningrum et al., "Kurikulum Dan Metode Pembelajaran Pada Masa Pandemi Covid-19 the Implementation of Character Education Integrated To Curriculum and Learning Methods During Covid19 Pandemic," AULADUNA: Jurnal Pendidikan Dasar Islam 7, no. 2 (2020): 154-64.

7 I Wayan Eka Santika, "Pendidikan Karakter Pada Pembelajaran Daring," Indonesian Values and Character Education Journal 3, no. 1 (2020): 11.
} 
pembelajaran. Selama observasi ini peneliti berusaha mencatat kebiasaan di kelas dan kultur sekolah yang tetap dijalankan selama pembelajaran jarak jauh. Pengumpulan data juga dilakukan melalui wawancara dengan pihak terkait, baik kepala sekolah yang diwakili oleh Waka Kesiswaan sebagai pemangku kebijakan maupun guru sebagai eksekutor lapangan, serta dokumentasi yang diperoleh dari kegiatan pembelajaran selama pandemi. Wawancara dengan guru peneliti lakukan untuk menggali informasi mengenai bagaimana guru melaksanakan proses pembelajaran jarak jauh dengan tetap menginternalisasikan pendidikan karakter. Untuk wawancara dengan kepala sekolah peneliti lakukan untuk mengetahui kebijakan yang ditetapkan sebagai pendukung dalam pelaksanaan pendidikan karakter. Data yang diperoleh dari observasi, wawancara, dan dokumentasi kemudian dianalisis melalui tiga tahapan yaitu reduksi data, penyajian data, dan penarikan kesimpulan. ${ }^{8}$

\section{Pembahasan}

\section{Pendidikan Karakter}

Pendidikan karakter merupakan salah satu bagian terpenting dalam pendidikan personal siswa. Karakter (character) merupakan serapan dari bahasa Yunani yakni "charassein" yang bermakna menggambar, mengukir, atau melukis. ${ }^{9}$ Dalam makna sederhana, dapat dipahami dengan sesuatu yang telah terbentuk, baik secara alamiah ataupun didukung oleh faktor lingkungan sekitarnya. Dalam Kamus Besar Bahasa Indonesia (KBB) kata karakter berarti sifat atau budi pekerti, dan juga akhlak yang dimiliki oleh seseorang, serta menjadi ciri khusus dari tiap personal seseorang. ${ }^{10}$ Apabila didefinisikan secara luas, pengertian karakter dapat dijelaskan sebagai bentuk tingkah laku, simbol, atau ciri khas yang melekat dalam diri seseorang.

Thomas Lickona, pionir pendidikan karakter, memaknai pendidikan karakter sebagai bentuk pendidikan moral yang berorientasi pada proses pembentukan kepribadian dari tiap individu yang hasilnya dapat diketahui berdasarkan perilaku nyata yang ditunjukkan seseorang dalam kehidupan sehari-hari. ${ }^{11}$ Karakter juga merupakan gambaran watak dari seseorang, yang mana perwujudan ini diperoleh melalui proses internalisasi diri dari lingkungan yang ada di sekitarnya. Wujud karakter dari seseorang

\footnotetext{
8 Asfi Manzilati, Metodologi Penelitian Kualitatif: Paradigma, Metode, Dan Aplikasi (Malang: Universitas Brawijaya press, 2017).

${ }^{9}$ Ajad Sudrajat, "Mengapa Pendidikan Karakter?," Jurnal Pendidikan Karakter 1, no. 1 (2011): 48.

${ }^{10}$ Kemendikbud, "Kamus Besar Bahasa Indonesia," kbbi.kemedikbud.go.id, accessed March 8, 2021, https://kbbi.kemdikbud.go.id/entri/karakter.

${ }^{11}$ Johansyah, "Pendidikan Karakter Dalam Islam," Jurnal Ilmiah Islam Futura 9, no. 1 (2011): 87.
} 
akan tercipta baik apabila dari proses yang terbentuk seluruhnya didasarkan pada aspekaspek yang memiliki nilai positif, seperti moral, akhlak, etika, dan lain sebagainya yang oleh masyarakat secara luas telah disepakati.

Pendidikan karakter yang dilaksanakan di sekolah merupakan sebuah proses yang secara sadar sengaja terprogram dan direncanakan, dilakukan, serta memiliki tujuan dan target terukur. ${ }^{12}$ Pendidikan karakter juga harus dilaksanakan secara imbang dengan aspek akademik, sosial, dan emosional peserta didik sehingga mampu menghasilkan lulusan yang unggul dan berkarakter. ${ }^{13}$ Pendidikan karakter juga seharusnya dilakukan secara integral ke dalam semua mata pelajaran yang dipelajari oleh peserta didik. Dalam pelaksanaannya guru menjadi sosok sentral dalam kesuksesan internalisasi nilai-nilai karakter kepada peserta didik.

Dalam implementasinya, terdapat komponen penting mendasar yang menekan pada terbentuknya karakter seseorang sesuai dengan pandangan Thomas Lickona, di antaranya seperti pengetahuan moral, perasaan moral, serta tindakan moral. ${ }^{14}$ Pendidikan karakter diidentifikasikan sebagai sebuah sistem yang terbentuk oleh beberapa faktor dan berorientasi terhadap penerapan nilai karakter seseorang yang mencakup aspek kesadaran, pengetahuan, serta kepatuhan untuk melaksanakan nilainilai yang termuat di dalamnya, yakni moral, akhlak, etika, kesopanan, ataupun nilainilai positif lainnya guna menumbuhkan jiwa berkarakter positif pada seseorang.

Salah satu kutipan yang disebutkan oleh Zubaidi menyatakan bahwa pendidikan karakter sejatinya memiliki beberapa fungsi, diantaranya: sebagai upaya perwujudan serta pengembangan potensi seseorang, sebagai penguatan serta perbaikan kualitas diri, dan sebagai filter diri. ${ }^{15}$ Adapun tujuan pendidikan karakter ini diberlakukan agar siswa mampu terbiasa untuk melakukan dan menerapkan norma-norma positif yang ada di lingkungan sekitarnya agar di kemudian hari ia tidak mudah untuk melakukan hal-hal yang amoral dan merugikan orang lain. ${ }^{16}$ Di samping itu, wujud pendidikan karakter bertujuan pula untuk membangun kepribadian personal seseorang agar terbentuk perilaku yang baik, jujur, memiliki sikap tanggung jawab, sikap saling menghargai dan menghormati orang lain, berkepribadian adil, berjiwa pekerja keras, tidak bersikap

\footnotetext{
${ }^{12}$ Sukiyat, Strategi Implementasi Pendidikan Karakter (Surabaya: Jakad Media Publishing, 2020).

${ }^{13}$ Ridwan Abdullah Sani, Inovasi Pembelajaran (Jakarta: Bumi Aksara, 2013).

${ }^{14}$ Binti Maunah, "Implementasi Pendidikan Karakter Dalam Pembentukan Kepribadian Holistik Siswa," Jurnal Pendidikan Karakter 5, no. 1 (2015): 98.

${ }^{15}$ Santika, "Pendidikan Karakter Pada Pembelajaran Daring."

${ }^{16}$ Evinna Cinda Hendriana and Arnold Jacobus, "Implementasi Pendidikan Karakter Di Sekolah Melalui Keteladanan Dan Pembiasaan,” Jurnal Pendidikan Dasar Indonesia 1, no. 2 (2016): 26.
} 
diskriminatif, dan karakter positif lainnya. ${ }^{17}$ Proses pembentukan karakter ini perlu direalisasikan dengan berbagai cara, salah satunya adalah melalui proses habituasi diri terhadap hal-hal positif yang diterapkan dalam aktifitas kehidupannya. Dengan metode pembiasaan akan terbentuk karakter walaupun membutuhkan proses yang relatif lama dan berkesinambungan. ${ }^{18}$

Berdasarkan penjabaran di atas dapat kita ambil garis besar bahwa pengertian dan tujuan pendidikan karakter adalah upaya penyampaian pendidikan watak, budi pekerti, moral, nilai, dan bentuk pendidikan karakter lainnya yang dilakukan secara terarah dan sitematis, dilakukan agar seseorang dapat mengembangkan kemampuan olah pikir dan rasanya sehingga mampu melakukan nilai kebaikan, tepat mengambil tindakan, serta memutuskan sesuatu dengan berdasar pada nilai positif seperti tanggung jawab, jujur, serta menghargai orang lain. Terbentuknya karakter seseorang sebenarnya tidak mutlak hanya diperoleh dari sekolah saja, tetapi terdapat faktor lain yang merupakan bagian dari proses terbentuknya karakter sendiri, yakni kebiasaan, naluri, kemauan, pendidikan, dan lingkungan. ${ }^{19}$

\section{Strategi Pendidikan Karakter}

Setidaknya terdapat enam strategi dalam membentuk karakter peserta didik di mana keenam hal ini membutuhkan proses yang stimulan dan dilakukan secara berkesinambungan. Keenam strategi tersebut antara lain; ${ }^{20}$

1. Habituasi dan pembudayaan

Kehidupan sekolah hendaknya terjadi dalam satu pola yang berulang-ulang dan terikat oleh jadwal yang ketat. Hal ini akan memengaruhi kebiasaan pendidikan karakter semua anggota sekolah. Suasana sekolah yang disiplin akan berdampak besar pada kehidupan siswa khususnya di lingkungan sekolah dan akan terbawa pula dalam lingkungan bermasyarakat. Masyarakat sekolah harus senantiasa memandang hidup berdisiplin sebagai salah satu aset utama pembinaan karakter siswa.

2. Membelajarkan hal-hal yang baik (moral knowing)

\footnotetext{
${ }^{17}$ Hendriana and Jacobus.

${ }^{18}$ Rasmuin and Desti Widiani, "Strategy and Implementation of Character Education in Era of Society 5.0" (International Conference on Engineering, Technology and Social Science (ICONETOS 2020), Atlantis Press, 2021), 575-82, https://doi.org/10.2991/assehr.k.210421.084.

${ }^{19}$ Alwazir Abdusshomad, "Pengaruh Covid 19 Terhadap Penerapan Pendidikan Karakter Dan Pendidikan Islam,” Qalamuna Jurnal Pendidikan, Sosial, Dan Agama 12, no. 2 (2020): 111-12.

${ }^{20}$ Maragustam Siregar, Filsafat Pendidikan Islam: Menuju Pembentukan Karakter Menghadapi Arus Global (Yogyakarta: Kurnia Kalam Semesta, 2014).
} 
Sekolah juga perlu menekankan aspek kognitif atau pengetahuan terkait dengan hal-hal yang boleh dilakukan dan hal-hal yang tidak boleh dilakukan oleh semua warga. Dengan mengetahui hal-hal yang baik ini berarti dia memahami bagaimana cara untuk mengimplementasikannya dalam kehidupan nyata.

3. Merasakan dan mencintai yang baik (feeling and loving the good)

Keinginan untuk melakukan perbuatan baik berasal dari kecintaan akan perbuatan baik tersebut. Aspek cinta inilah yang menurut Piaget merupakan sumber energi, yang secara efektif dapat membuat seseorang memiliki karakter yang konsisten antara pengetahuan (moral knowing) dan tindakan (moral action).

4. Tindakan yang baik (moral acting)

Moral acting adalah bagaimana mengubah pengetahuan moral menjadi perilaku yang sebenarnya. Perilaku moral semacam ini adalah hasil (outcome) dari dua komponen karakter lainnya (moral knowing dan moral feeling). Untuk memahami apa yang mendorong seseorang untuk bertindak secara etis, kita harus mempelajari tiga aspek karakter lainnya, yaitu kemampuan, kemauan, dan kebiasaan.

5. Keteladanan dari lingkungan sekitar (moral modelling)

Peserta didik sebagai manusia pembelajar membutuhkan role model dalam membentuk karakternya. Di sinilah peran vital seorang guru maupun orang tua dalam mengarahkan anak didiknya menuju manusia berkarakter. Orang tua dan guru harus terlebih dahulu menyontohkan sebagai sosok pribadi yang patut untuk menjadi teladan bagi mereka. Contoh keteladanan yang dilakukan secara terus menerus ini akan menunjang habituasi pendidikan karakter secara optimal.

6. Taubat

Cara terakhir yang ditempuh oleh seseorang yang belum bisa menjadi pribadi yang berkarakter unggul adalah melakukan pertaubatan, dengan menyesali perbuatan buruk yang pernah dilakukan dan berusaha semaksimal mungkin untuk tidak mengulanginya kembali.

\section{Konsep Pendidikan Era Pandemi Covid 19}

Di masa pandemi, kesehatan masyarakat bangsa merupakan salah satu hal yang paling diperhatikan dan menjadi prioritas pemerintah. Hal ini dapat dibuktikan dari adanya himbauan keras bagi seluruh masyarakat Indonesia, baik dari penyelenggara sektor ekonomi, pariwisata, pendidikan, dan sektor lainnya untuk melaksanakan dan 
menjalankan regulasi baru dari pemerintah, dengan menerapkan protokol kesehatan yang ada. Dengan adanya keputusan tersebut, sektor pendidikan berupaya keras untuk membuat inovasi baru dalam belajar yang dapat digunakan sebagai sistem belajar sementara bagi berlangsungnya proses pendidikan. Oleh karenanya dikeluarkanlah satu keputusan oleh Sekjen Kemendikbud, yakni keputusan Nomor 15 tahun 2020 yang membahas tentang pedoman khusus pelaksanaan pembelajaran yang diselenggarakan secara daring (online) dari rumah untuk mencegah serta meminimalisir terjadinya penyebaran Covid-19 di lingkungan lembaga pendidikan. Hal ini juga sebagai bentuk penyokong bahwa meski dalam keadaan yang demikian hak seseorang dalam belajar dan proses pembelajaran harus tetap diberikan.

Model pembelajaran yang dijadikan sebagai model belajar masa pandemi adalah konsep pembelajaran jarak jauh (PJJ). Tidak dapat dimungkiri bahwa konsep pembelajaran ini sangat sulit untuk diselenggarakan secara optimal jika dibandingkan dengan pola pembelajaran sebelumnya. ${ }^{21}$ Salah satu yang paling menonjol dalam perbedaan pelaksanaan konsep belajar pada saat ini adalah adanya pembelajaran yang tidak dilaksanakan dengan melakukan interaksi secara langsung. Pembelajaran seperti ini dinilai kurang efektif, karena terbatasnya komunikasi yang terjalin antara pendidik dan peserta didik. Hal inipun akhirnya juga berpengaruh terhadap penangkapan informasi yang disampaikan oleh guru yang tak jarang juga tidak mampu dipahami dengan jelas oleh siswa. ${ }^{22}$ Sebenarnya konsep pembelajaran jarak jauh ini, jika ditelaah lebih kritis dapat membawa karakter positif bagi peserta didik, yaitu karakter kemandirian dan pantang menyerah.

Pemanfaatan berbagai platform media online akhirnya menjadi pilihan atau jalan alternatif dalam pendidikan agar keberlangsungan pembelajaran tetap terus terlaksana. Konsep pendidikan pada saat ini disesuaikan dengan menerapkan beberapa prinsip, salah satunya adalah dengan memprioritaskan aspek keselamatan serta kesehatan seluruh masyarakat. ${ }^{23}$ Ini merupakan prinsip yang harus diterapkan tanpa terkecuali oleh seluruh lembaga pendidikan yang ada, baik dari jenjang terendah hingga pada jenjang tertinggi. Secara umum ada 2 prinsip peraturan penyelenggaraan pendidikan khususnya di masa Covid-19, di antaranya:

\footnotetext{
${ }^{21}$ Purwanti Zizca Diana, Denik Wirawat, and Sholeha Rosalia, "Blended Learning Dalam Pembentukan Kemandirian Belajar,” Alinea: Jurnal Bahasa, Sastra, Dan Pengajaran 9, no. 1 (2020): 16-22.

${ }^{22}$ Purandina and Wanaya, "Pendidikan Karakter Di Lingkungan Keluarga Selama Pembelajaran Jarak Jauh Pada Masa Pandemi COVID-19.”

${ }^{23}$ Purandina and Wanaya.
} 
1. Prioritas keselamatan dan kesehatan. Prinsip ini merupakan prinsip mutlak yang harus diimplementasikan dalam penerapan pendidikan masa Covid-19. Seluruh pihak terkait tanpa terkecuali baik tenaga kerja, peserta didik harus mematuhi regulasi yang ada demi tercapainya kemaslahatan bersama.

2. Perkembangan peserta didik dalam aspek fisik, mental, dan psikososial. Hal ini merupakan prinsip penting yang harus diperhatikan, baik oleh guru ataupun orang tua. Perlu adanya kehangatan yang tercipta dalam lingkungan peserta didik, agar tidak terjadi ketimpangan yang dipengaruhi oleh lingkungannya. ${ }^{24}$

Dua poin ini merupakan prinsip mendasar dan penting, yang tidak bisa dijalankan hanya dengan mengacu pada satu prinsip saja, namun mesti ada keselarasan dan keseimbangan di antara keduanya. Konsep pembelajaran secara online menjadi alternatif yang tepat digunakan demi tetap berlangsungnya kegiatan pembelajaran. Interaksi yang harusnya terjadi antar pendidik dan peserta didik nyatanya juga masih dapat dilakukan meskipun harus dengan menggunakan perantara media. Terlepas dari hal tersebut, bagi sebagian orang pembelajaran pada saat ini dirasa cukup memberatkan. Banyak masyarakat yang dihimpit oleh keterbatasan dan ditekan oleh keadaan. Hal ini dapat kita ketahui dari respon masyarakat yang mengatakan bahwa banyak di antara mereka yang kurang mampu membeli smartphone, tidak mampu mengoperasikan media elektronik secara maksimal, serta keterbatasan-keterbatasan lainnya seperti ekonomi, daerah yang tidak cukup dijangkau oleh jaringan, kesibukan bekerja, dan beberapa faktor lainnya.

\section{Tantangan Penerapan Pendidikan Karakter di Masa Pandemi}

Di masa pandemi seperti ini penerapan pendidikan karakter mendapati tantangan tersendiri. Pasalnya pembelajaran yang dilakukan di rumah, menjadikan tidak maksimalnya proses penerapan pendidikan karakter dalam lingkup pendidikan formal. Secara garis besar terdapat beberapa hal yang menjadi tantangan penerapan pendidikan karakter di masa pandemi Covid-19 yakni :

1. Peserta didik kehilangan teladan seorang guru. Peran guru dalam upaya penerapan pendidikan karakter siswa di sekolah sangatlah besar. Guru menjelma sebagai seorang contoh atau teladan bagi para siswa dalam berprilaku. Secara langsung atau tidak langsung, segala tindak tutur guru akan menjadi sorotan siswanya.

\footnotetext{
${ }^{24}$ Kemendikbud, "Penyesuaian Kebijakan Pembelajaran Di Masa Pandemi Covid 19” (Jakarta, 2020).
} 
Dengan keadaan demikian, kurang adanya interaksi secara langsung dengan guru, maka siswa terkadang juga tidak memedulikan kedisiplinan seperti yang biasa dilakukan di kelas. Pendidikan jarak jauh tidak dapat dipungkiri menjadikan peserta didik kehilangan sosok guru yang menjadi contoh di kelas, baik dalam hal berbicara, bertindak, ataupun berperilaku.

2. Kontrol yang kurang maksimal. Pendidikan karakter yang semula harus dilaksanakan berdasakan kontrol dari guru, maka pada saat pandemi seperti ini, guru tidak bisa memantau perkembangan anak secara maksimal. Belum lagi ketika di rumah anak tidak dikontrol oleh orang tua, maka mungkin saja anakanak bisa berperilaku tidak adil dan tidak mandiri dalam mengatur waktu belajarnya. Hal ini akan semakin pelik di saat anak diminta untuk mengakses pelajaran melalui internet tanpa adanya pengawasan dan kontrol yang baik, maka akan sangat mungkin anak membuka portal yang tidak semestinya dilihat olehnya. ${ }^{25}$ Hal ini mungkin akan teratasi apabila orang tua peserta didik berkenan untuk bekerja sama dengan guru dalam mengontrol kegiatan belajar siswa. Namun bagi anak-anak yang tidak mendapat pengawasan lebih dari orang tua mereka, maka mungkin saja koneksi yang peserta didik akses akan tersambung dan digunakan pada hal-hal yang tidak positif. Sehingga hal ini secara tidak langsung menghambat pula terhadap penguatan pendidikan karakter siswa.

3. Sikap orang tua terhadap anak. Peran dan sikap orang tua untuk mendampingi mengontrol dan mengawasi kedisplinan anak di sini sangat penting. Anak akan berperilaku semaunya dan terkesan acuh terhadap kewajiban belajarnya apabila tidak diawasi dengan baik oleh orang tua. Mungkin bagi sebagian anak yang hidup di lingkungan keluarga yang sudah menerapkan kedisiplinan terhadap putra putrinya tidak akan mempermasalahkan hal ini. Karena disiplin, mandiri, dan tepat waktu merupakan hal yang sudah menjadi kebiasaan dalam keluarganya, namun kasus demikian akan berlaku berbeda, apabila dalam lingkup keluarga yang tidak menerapkan budaya positif di dalamnya. Oleh karenanya, peran orang tua sebagai pengganti guru dalam hal controlling sangat penting dan berpengaruh besar dalam upaya pembentukan karakter peserta didik. Karena memang kondisi yang tidak memungkinkan untuk guru mengawasi secara langsung, maka orang tua setidaknya meluangkan waktunya untuk mengontrol kegiatan belajar siswa,

${ }^{25}$ Darmiatun Suryatri Dayatun, Implementasi Pendidikan Karakter Di Sekolah (Yogyakarta: Gava Media, 2013). 
pekerjaan sekolah siswa, atau hal apapun yang dapat mengajarkan anak sadar dan tanggap akan kewajiban yang harus dikerjakannya.

Beberapa problem di atas sebenarnya tidak secara keseluruhan dialami oleh peserta didik. Namun berdasarkan penelitian yang kami lakukan, sedikitnya tiga problem tersebut yang menjadi tantangan tersendiri guna terwujudnya pendidikan karakter di lingkungan sekolah yang dilakukan di masa pandemi.

\section{Strategi Pendidikan Karakter di Era Pandemi di MAN 2 Banyuwangi}

Kita ketahui bahwa sebelum adanya wabah yang menjangkit negara ini, pemerintah telah merumuskan salah satu poin penting yang dituangkan dalam peraturannya tentang pendidikan nasional, yakni terkait penguatan pendidikan karakter. Kebijakan yang dirumuskan oleh pemerintah mengenai pendidikan karakter, disusun regulasinya berdasarkan pada empat falsafah utama bangsa Indonesia yakni Pancasila, nilai-nilai UUD 1945, NKRI, dan Bhineka Tunggal Ika. Apabila kita tarik garis besarnya, seluruh falsafah tersebut akan memunculkan aspek-aspek yang berorientasi pada nilai-nilai religiusitas, aspek nasionalisme, aspek kemandirian, aspek gotong royong, dan adanya nilai integritas. ${ }^{26}$

Strategi yang dirancangpun sudah sangat jelas bahwa seluruh aspek tersebut mesti diimplementasikan secara maksimal. Penerapan pendidikan karakter di sekolah dapat diterapkan di beberapa tempat, misalnya seperti diterapkan dalam lingkungan sekolah secara umum, kelas, dan lingkungan sekolah melalui budaya sekolah. Pendidikan karakter sejatinya bukanlah upaya mutlak yang harus dibentuk dan dilaksanakan berdasarkan kebijakan dari pemerintah. Pendidikan karakter nyatanya bisa terbentuk oleh lingkungan terdekat kita sendiri. Namun perlu kita tahu bahwa penyelenggaraan proses pendidikan karakter yang dilaksanakan di sekolah faktanya juga mampu menunjang terbentuknya karakter positif anak yakni lewat pembiasaan baik di lingkungan sekolah. Sebenarnya apa yang telah dirumuskan sebelumnya terkait strategi penerapan pendidikan karakter ini juga bisa dijadikan sebagai strategi penerapan pendidikan karakter di masa pandemi. Hanya saja pendidik harus sedikit memutar otak dan berinovasi mengenai bagaimana cara mengaplikasikannya dengan kondisi yang terbatas seperti sekarang.

\footnotetext{
${ }^{26}$ Kemendikbud, "Penyesuaian Kebijakan Pembelajaran Di Masa Pandemi Covid 19." 
Berdasarkan observasi yang peneliti lakukan di MAN 2 Banyuwangi setidaknya ada tiga strategi yang dilakukan dalam pendidikan karakter di masa pembelajaran daring selama pandemi ini.

1. Pertama, bentuk suasana belajar secara online didesain semirip mungkin dengan kondisi real di sekolah seperti sebelum masa pandemi, yakni desain pembelajaran tatap muka. Hal ini dilakukan agar siswa tetap menjaga kedisiplinan seperti ketika ia belajar di sekolah. Misalnya dari segi waktu, pakaian, dan sebagainya. Hal seperti ini pun juga harus dikemas sedemikian rupa mengikuti kurikulum sementara pemerintah yang berisi tentang materi dan capaian kumulatif yang lebih disederhanakan. Jadi guru harus menyesuaikan kurikulum sementara ini dengan konsep belajar jarak jauh agar tidak saling memberatkan.

2. Kedua, konsisten menerapkan budaya sekolah yang biasa dikerjakan di sekolah dengan tetap menyesuaikan dengan kondisi yang ada. Misalnya seperti berdoa bersama sebelum dan sesudah belajar, mengingatkan waktu salat dhuha, tetap melaksanakan budaya 5S dan sebagainya. MAN 2 Banyuwangi dikenal sebagai salah satu Madrasah favorit yang memiliki peraturan madrasah yang cukup ketat serta budaya madrasah yang bernafaskan dan menjunjung tinggi nilai kedisiplinan dan keislaman. Peraturan dan budaya madrasah inilah yang kemudian dijadikan salah satu strategi dalam upaya penguatan karakter siswa. Pengintegrasian budaya madrasah ke dalam pendidikan atau sistem pembelajan jarak jauh ini digunakan sebagai alternatif yang sifatnya saling melengkapi. Di Madrasah ini, pembiasaan yang digiatkan dalam masa pandemi sebagai upaya penerapan pendidikan karakter salah satunya adalah siswa diharuskan untuk tetap melakukan dan menjaga rutinitasnya dalam melaksanakan salat dhuha dan baca Quran di rumah sebelum pembelajaran dimulai. Ini merupakan salah satu bentuk budaya madrasah yang wajib dilaksanakan di MAN 2 Banyuwangi dan tetap harus dikerjakan meskipun siswa berada di rumah masing-masing. Selain itu guru juga memberikan materi tentang bagaimana cara berinteraksi dengan baik ketika akan atau sedang berkomunikasi dengan guru dan juga teman dalam proses pembelajaran jarak jauh. Pastinya guru memberikan contoh yang baik kepada siswanya dengan mengimplementasikannya melaui diskusi dalam forum online. Mulai dari cara bertanya, menjawab, meminta bantuan, dan sebagainya. Kemudian juga memperhatikan kedisiplinan dan ketepatan waktu ketika akan 
atau sedang berada dalam forum online. Seperti siswa diharuskan tetap berpakaian rapi dan masuk ke dalam forum dengan tepat waktu. Jadi meskipun belajar dilaksanakan di rumah, siswa tetap harus berpenampilan rapi dan menjaga kedisiplinan menyesuaikan dengan kebiasaan sebelumnya. ${ }^{27}$

3. Ketiga, menjalin kerja sama yang solid antara guru dan orang tua. Dalam hal ini peran orang tua dalam mengontrol belajar dan kebiasaan siswa di rumah sangat signifikan. Mekipun dalam anggapan lain ini cukup membebani pada orang tua, namun kerja sama seperti ini sangat penting agar guru tahu seberapa besar penerapan pendidikan karakter saat belajar di rumah. Guru juga perlu mengadakan visit home sesekali apabila memang memungkinkan untuk dilakukan. Dapat diambil kesimpulan bahwa penerapan pendidikan karakter dapat dilakukan dengan metode habituasi atau pembiasaan secara berkala. Pembiasaan ini dimulai dengan diajarkan kemudian dibiasakan, dilatih untuk menjadi suatu komitmen, menjadi kebiasaan, menjadi karakter, dan akhirnya menjadi budaya. ${ }^{28}$

Strategi pendidikan karakter di atas merupakan adaptasi dari proses penanaman karakter pada peserta didik yang selama ini dilakukan di sekolah. Menurut Waka Kesiswaan, M. Tashil, pendidikan karakter yang dilakukan di masa pandemi ini merupakan penyederhanaan proses yang sudah dilakukan di sekolah. Menganut pada kaidah ushul fikih bahwa "apa yang tidak bisa dicapai seluruhnya maka jangan ditinggal semuanya" maka menurut beliau meskipun tidak semua karakter unggul siswa bisa dilakukan melalui pembelajaran jarak jauh secara maksimal, minimal inti dari pendidikan karakter bisa tersampaikan. ${ }^{29}$

Pengkondisian suasana kelas online yang didesain sedemikian rupa menyerupai kelas offline merupakan bagian dari online classroom management. Manajemen kelas tersebut memiliki fungsi untuk membentuk sikap dan karakter peserta didik seperti dalam kehidupan nyata. Desain yang dilakukan di MAN 2 Banyuwangi ini telah disepakati bersama oleh para guru sehingga terjalin kesesuaian antara guru yang satu dengan yang lainnya. Desain pembelajaran dan pembiasaan dalam kelas online yang serupa dengan kehidupan nyata ini merupakan cara yang efektif dilakukan dalam internalisasi karakter unggul kepada peserta didik. Hal ini juga sejalah dengan hasil

\footnotetext{
${ }^{27}$ Sules, "Wawancara" (Banyuwangi, 2021).

${ }^{28}$ Abdusshomad, "Pengaruh Covid 19 Terhadap Penerapan Pendidikan Karakter Dan Pendidikan Islam."

${ }^{29}$ Muhammad Tashil, "Wawancara” (Banyuwangi, 2021).
} 
penelitian yang dilakukan oleh Halim dkk. yang dilakukan di SMA Muhammadiyah 7 Yogyakarta. Ia mengungkapkan bahwa penerapan online classroom management yang baik mampu untuk mengontrol sikap dan perilaku siswa selama pandemi. Meskipun dalam praktiknya masih terjadi beberapa kendala karena proses adaptasi. ${ }^{30}$

Pada praktiknya, menurut Tashil, wali kelas maupun guru-guru pengampu mata pelajaran selalu mengingatkan akan aktifitas harian yang sudah biasa dilakukan di lingkungan sekolah melalui alat komunikasi di luar kegiatan belajar mengajar. Khususnya wali kelas, mereka selalu mengingatkan anak didiknya setiap pagi untuk melaksanakan salat dhuha serta ketika siang hari saatnya zuhur wali kelas juga mengingatkan untuk terlebih dahulu melaksanakan salat sebelum makan siang. Dalam hal ini orang tua atau wali murid diberikan tugas oleh sekolah untuk bertindak sebagai imam. Hal ini untuk memastikan bahwa para peserta didik senantiasa melaksanakan shalat dhuha dan zuhur di rumah masing-masing. ${ }^{31}$

Proses pembelajaran yang baik, baik itu pembelajaran secara offline maupun online membutuhkan konsistensi dari para pelakunya. Pendidik dan peserta didik harus sama-sama konsisten dalam kegiatan belajar mengajar. Hal ini dikarenakan aktifitas belajar tidak semata-mata dibatasi oleh ruang kelas, melainkan semua aspek yang saling memberikan kontribusi. Oleh karena itu diperlukan ketaatan dan konsistensi dari seluruh daya dukung agar pembelajaran bisa optimal. ${ }^{32}$ Konsistensi yang diterapkan oleh MAN 2 Banyuwangi selama pembelajaran online ini bertujuan agar budaya karakter yang telah dilakukan di sekolah sebelum adanya pandemi tetap terjaga dan terbiasa dilakukan oleh para peserta didik meskipun mereka tidak datang langsung ke sekolah.

Dari informasi yang peneliti peroleh dari Ibu Sules, salah satu guru MAN 2 Banyuwangi, pada saat kegiatan belajar mengajar yang dilakukan melalui platform zoom meeting maupun google meet, semua siswa diwajibkan untuk mengenakan seragam masing-masing. Hal ini untuk menjaga kedisiplinan sebagaimana praktik di sekolah. Sebelum KBM dimulai terlebih dahulu guru mengajak siswa untuk membaca

\footnotetext{
30 Halim Purnomo et al., "Pendidikan Karakter Islami Pada Online Class Management Di SMA Muhammadiyah 7 Yogyakarta Selama Pandemi Covid-19," Jurnal Tarbiyatuna 11, no. 1 (2020): 91-100, https://doi.org/10.31603/tarbiyatuna.v11i1.3456.

31 Tashil, "Wawancara."

${ }^{32}$ Nur Afif, Pembelajaran Berbasis Masalah Perspektif Al-Qur'an, ed. Desy Ayuningrum (Tuban: Karya Litera Indonesia, 2019).
} 
Al-Qur'an untuk menanamkan nilai-nilai religius. Dalam hal ini proses pendidikan karakter masih bisa dikontrol oleh masing-masing pengampu mata pelajaran. ${ }^{33}$

Faktor utama penunjang kesuksesan pembelajaran online yang dilakukan oleh berbagai sekolah selama pandemi ini adalah adanya infrastuktur yang memadai, mulai dari jaringan internet sampai gawai yang dimiliki oleh para siswa sebagai media berinteraksi dengan guru dan sesama siswa. Paket data internet juga menjadi kunci utama dalam kelancaran proses KBM. Selain itu kesiapan dan kesigapan pendidik dalam menyiapkan skenario pembelajaran online juga menjadi yang tak kalah pentingnya. $^{34}$

Untuk melihat kondisi langsung bagaimana proses pendidikan karakter berlangsung selama KBM jarak jauh di masa pandemi ini, peneliti terjun langsung ke dalam kelas-kelas virtual yang diselenggarakan oleh guru mata pelajaran. Pada tahap ini para peserta didik masih sangat bisa terkontrol karena mereka semua diwajibkan untuk on camera sehingga guru bisa memonitornya secara langsung. Semua peserta didik menggunakan seragam sekolah sesuai dengan harinya secara rapi. Pada awal KBM semua murid diajak untuk membaca Al-Qur'an oleh guru. Mereka diminta untuk menyiapkan Al-Qur'an masing-masing di rumah. Pembacaan ini berlangsung antara 510 menit untuk tiap pergantian jam pelajaran. Dalam proses KBM online melalui video conference yang berlangsung terkadang terdapat siswa yang secara tidak sengaja keluar dari platform. Hal ini disebabkan oleh jaringan internet di wilayah siswa tersebut tidak begitu stabil. Solusi dari guru pengampu mata pelajaran adalah menyuruh anak yang bersangkutan untuk menonaktifkan kamera agar tetap terkoneksi di dalam kelas. Namun secara berkala guru mengecek keberadaan siswa dengan memerintahkannya untuk menghidupkan kamera.

Untuk nilai-nilai kejujuran, kedisplinan, dan tanggung jawab, para guru bekerjasama dengan para wali murid untuk ikut serta mengawasi anaknya. Guru senantiasa menginformasikan tugas-tugas yang diberikan kepada wali murid melalui grup WA masing-masing kelas. Wali murid diminta untuk melaporkan kegiatan pembelajaran anaknya ketika proses kegiatan belajar mengajar tidak dilaksanakan melalui platform zoom maupun google meet. Perkembangan pendidikan karakter baik dari aspek religius, kedisiplinan, tanggung jawab, dan kejujuran juga secara berkala

\footnotetext{
33 Sules, "Wawancara."

${ }^{34}$ Luh Devi Herliandry et al., "Pembelajaran Pada Masa Pandemi Covid-19," JTP - Jurnal Teknologi Pendidikan 22, no. 1 (2020): 65-70, https://doi.org/10.21009/jtp.v22i1.15286.
} 
dikontrol oleh masing-masing wali kelas. Di sinilah orang tua memiliki peran yang vital dalam menyukseskan proses pendidikan karakter selama pembelajaran jarak jauh. ${ }^{35}$

Kerjasama yang baik antara pihak sekolah dengan orang tua akan sangat membantu proses KBM pada masa pandemi seperti ini. Hal ini sebagaimana yang diungkapkan oleh penelitian yang dilakukan oleh Yoga bahwa pendidikan yang dilakukan secara online bisa terlaksana secara optimal jika terdapat kerjasama yang baik antara sekolah dan wali murid. ${ }^{36}$ Fakta ini diperkuat oleh hasil penelitian yang dilakukan oleh Galih, dkk bahwa proses pembiasaan pada pendidikan karakter dapat tercapai dengan adanya sinergitas antara implementasi kurikulum, kebijaksanaan guru serta peran orang tua sebagai asesor pendidikan karakter anaknya masing-masing. Kerjasama yang dilakukan oleh MAN 2 Banyuwangi dengan wali murid sudah terjalin cukup baik sebagaimana yang disampaikan oleh waka kesiswaan. Guru juga sesekali mengadakan kunjungan khusus kepada murid yang memiliki kendala dalam proses pembelajaran untuk mengetahui secara langsung realita di lapangan sehingga bisa merumuskan solusi dari problem yang dihadapi siswa tersebut. ${ }^{37}$

\section{Penutup}

Berdasarkan pemaparan di atas, bahwa adanya Covid-19 di Indonesia sangat mempengaruhi terhadap segala lini kehidupan tak terkecuali dunia pendidikan. Pelaksanaan pendidikan karakter menjadi salah satu yang mendapatkan dampak yang cukup besar dalam prosesnya. Dengan segala bentuk tantangan yang ada maka harus ada pula pembaruan yang bisa dilakukan untuk terus diselenggaraannya pendidikan karakter di lingkungan pendidikan meskipun pelaksanaannya hanya dilakukan secara jarak jauh. Beberapa hal yang dapat dilakukan untuk menunjang keberlangsungan pendidikan karakter di masa pandemi covid 19 ini adalah bagaimana lembaga pendidikan mampu melakukan habituasi yang sama dengan masa sebelum pandemi namun tetap bisa dilakukan meskipun di masa pandemi. Tetap melaksanakan budaya sekolah yang bernilai penerapan karakter di dalamnya dengan disesuaikan dengan konsep pendidikan jarak jauh, serta kerja sama yang dilakukan oleh guru dan orang tua agar mampu menjadi pengontrol peserta didik agar tetap menjalankan proses pendidikan karakter meskipun hanya dilakukan di rumah, mengingat sejatinya pendidikan karakter

\footnotetext{
35 Tashil, "Wawancara."

${ }^{36}$ Purandina and Wanaya, "Pendidikan Karakter Di Lingkungan Keluarga Selama Pembelajaran Jarak Jauh Pada Masa Pandemi COVID-19."

37 Tashil, "Wawancara."
} 
bukanlah merupakan proses pendidikan yang berbentuk angka, namun realisasinya menjadi poin positif bagi peserta didik ke depannya.

\section{Daftar Rujukan}

Abdusshomad, Alwazir. "Pengaruh Covid 19 Terhadap Penerapan Pendidikan Karakter Dan Pendidikan Islam." Qalamuna Jurnal Pendidikan, Sosial, Dan Agama 12, no. 2 (2020): 111-12.

Afif, Nur. Pembelajaran Berbasis Masalah Perspektif Al-Qur'an. Edited by Desy Ayuningrum. Tuban: Karya Litera Indonesia, 2019.

Dayatun, Darmiatun Suryatri. Implementasi Pendidikan Karakter Di Sekolah. Yogyakarta: Gava Media, 2013.

Diana, Purwanti Zizca, Denik Wirawat, and Sholeha Rosalia. "Blended Learning Dalam Pembentukan Kemandirian Belajar." Alinea: Jurnal Bahasa, Sastra, Dan Pengajaran 9, no. 1 (2020): 16-22.

Hendriana, Evinna Cinda, and Arnold Jacobus. "Implementasi Pendidikan Karakter Di Sekolah Melalui Keteladanan Dan Pembiasaan." Jurnal Pendidikan Dasar Indonesia 1, no. 2 (2016): 26.

Herliandry, Luh Devi, Nurhasanah Nurhasanah, Maria Enjelina Suban, and Heru Kuswanto. "Pembelajaran Pada Masa Pandemi Covid-19." JTP - Jurnal Teknologi Pendidikan 22, no. 1 (2020): $65-70$. https://doi.org/10.21009/jtp.v22i1.15286.

Johansyah. "Pendidikan Karakter Dalam Islam.” Jurnal Ilmiah Islam Futura 9, no. 1 (2011): 87.

Kemendikbud. "Kamus Besar Bahasa Indonesia." kbbi.kemedikbud.go.id. Accessed March 8, 2021. https://kbbi.kemdikbud.go.id/entri/karakter.

_. "Penyesuaian Kebijakan Pembelajaran Di Masa Pandemi Covid 19." Jakarta, 2020.

Kholis, Tohir, and M. Syukri Azwar Lubis. Model Pendidikan Pesantren Salaf. Surabaya: Scopindo Media Pustaka, 2020.

Koesoema, Doni. Pendidikan Karakter Di Zaman Keblinger. Jakarta: Grasindo, 2016.

Manzilati, Asfi. Metodologi Penelitian Kualitatif: Paradigma, Metode, Dan Aplikasi. Malang: Universitas Brawijaya press, 2017.

Maunah, Binti. "Implementasi Pendidikan Karakter Dalam Pembentukan Kepribadian Holistik Siswa." Jurnal Pendidikan Karakter 5, no. 1 (2015): 98.

Mustikaningrum, Galih, Linda Pramusinta, Sri Ayu, and Muhtar Umar. "Kurikulum Dan Metode Pembelajaran Pada Masa Pandemi Covid-19 the Implementation of Character Education Integrated To Curriculum and Learning Methods During Covid-19 Pandemic." AULADUNA: Jurnal Pendidikan Dasar Islam 7, no. 2 (2020): 154-64.

Purandina, I Putu Yoga, and I Made Astra Wanaya. "Pendidikan Karakter Di Lingkungan Keluarga Selama Pembelajaran Jarak Jauh Pada Masa Pandemi COVID-19." Jurnal Ilmu Pendidikan 3, no. 2 (2020): 273. 
Purnomo, Halim, Firman Mansir, Tumin Tumin, and Suliswiyadi Suliswiyadi. "Pendidikan Karakter Islami Pada Online Class Management Di SMA Muhammadiyah 7 Yogyakarta Selama Pandemi Covid-19." Jurnal Tarbiyatuna 11, no. 1 (2020): 91-100. https://doi.org/10.31603/tarbiyatuna.v11i1.3456.

Rasmuin, and Desti Widiani. "Strategy and Implementation of Character Education in Era of Society 5.0," 575-82. Atlantis Press, 2021. https://doi.org/10.2991/assehr.k.210421.084.

Sani, Ridwan Abdullah. Inovasi Pembelajaran. Jakarta: Bumi Aksara, 2013.

Sanjaya, F. Ridwan, ed. 21 Refleksi Pembelajaran Daring Di Masa Darurat. Semarang: UNIKA Soegijapranata, 2020.

Santika, I Wayan Eka. "Pendidikan Karakter Pada Pembelajaran Daring." Indonesian Values and Character Education Journal 3, no. 1 (2020): 11.

Siregar, Maragustam. Filsafat Pendidikan Islam: Menuju Pembentukan Karakter Menghadapi Arus Global. Yogyakarta: Kurnia Kalam Semesta, 2014.

Sudrajat, Ajad. “Mengapa Pendidikan Karakter?” Jurnal Pendidikan Karakter 1, no. 1 (2011): 48.

Sukiyat. Strategi Implementasi Pendidikan Karakter. Surabaya: Jakad Media Publishing, 2020.

Sules. "Wawancara.” Banyuwangi, 2021.

Suprayitno, Adi, and Wahid Wahyudi. Pendidikan Karakter Di Era Milenial. Yogyakarta: Deepublish, 2020.

Tashil, Muhammad. "Wawancara.” Banyuwangi, 2021. 